\title{
INOVASI PEMBELAJARAN MELALUI TEKNOLOGI INFORMASI: PENGEMBANGAN MODEL PEMBELAJARAN MELALUI INTERNET
}

\author{
Yuliana \\ Pendidikan Islam UIN Sunan Gunung Djati Bandung \\ JI. Soekarno-Hatta, Gedebage, Bandung, Jawa Barat 40613 \\ Email: yuliana.jatiwangi@gmail.com
}

\begin{abstract}
ABSTRAK
Ketidakpuasan siswa terhadap pembelajaran konvensional semakin meningkatkan pemanfaatan internet dalam pembelajaran. Hal ini menjadi pendorong peranan teknologi informasi di dunia pendidikan. Penelitian ini bertujuan untuk mengidentifikasi inovasi pembelajaran melalui teknologi informasi, terutama berkaitan dengan pengembangan model pembelajaran melalui internet. Metode penelitian yang digunakan adalah kualitatif dan pengumpulan data dilakukan dengan studi literatur dan situs internet. Analisis data meliputi pengumpulan data, reduksi data, penyajian data, dan penarikan kesimpulan. Adapun contoh pengembangan model pembelajaran melalui internet adalah dengan memanfaatkan Ruangguru, Quipper, Zenius, Edmodo, Google Classroom dan model pembelajaran You-Do yang digagas oleh Cecep Gaos, guru Bahasa Inggis kelas V SD Puri Artha Karawang. Hasil penelitian menunjukan bahwa pengembangan model pembelajaran melalui internet meliputi penggunaan teori konstruktivisme, pendekatan pembelajaran yang berpusat pada siswa, strategi pembelajaran individual learning, metode pembelajaran tutorial, serta teknik dan taktik pembelajaran yang bersifat spesifik berbasis internet. Berdasarkan hasil penelitian tersebut dapat disimpulkan bahwa pembelajaran melalui internet dapat meningkatkan kualitas pembelajaran.
\end{abstract}

Kata kunci: inovasi pembelajaran, teknologi informasi, model pembelajaran, pembelajaran melalui internet

\begin{abstract}
Students' dissatisfaction with conventional learning increases the use of the internet in learning. This has become the driver of the role of information technology in the world of education. This study aims to identify learning innovations through information technology, especially related to the development of learning models via the internet. The research method used is qualitative and data collection is done by studying literature and internet sites. Data analysis includes data collection, data reduction, data presentation, and conclusion drawing. The example of developing an internet learning model is by utilizing Ruangguru, Quipper, Zenius, Edmodo, Google Classroom and You-Do learning models initiated by Cecep Gaos, a fifth grade English teacher at SD
\end{abstract}


Puri Artha Karawang. The results showed that the development of learning models through the internet included the use of constructivism theory, studentcentered learning approaches, individual learning learning strategies, tutorial learning methods, and internet-based learning techniques and tactics. Based on the results of these studies it can be concluded that learning through the internet can improve the quality of learning.

Key Words: learning innovation, information technology, learning models, internet learning

\section{PENDAHULUAN}

Perkembangan teknologi informasi beberapa tahun belakangan ini berkembang dengan kecepatan yang sangat tinggi, sehingga dengan perkembangan ini telah mengubah paradigma masyarakat dalam mencari dan mendapatkan informasi. Salah satu bidang yang mendapatkan dampak yang cukup berarti dengan perkembangan teknologi ini adalah bidang pendidikan (Prasetyo, 2017). Perkembangan teknologi di bidang informasi memberikan peluang pada dunia pendidikan untuk memanfaatkan semaksimal mungkin inovasi-inovasi teknologi informasi.

Pada hakikatnya proses pembelajaran merupakan proses komunikasi atau penyampaian pesan dari pengantar ke penerima. Pesan berupa materi pelajaran yang dituangkan ke dalam simbol-simbol komunikasi baik verbal (kata-kata dan tulisan) maupun nilai-nilai yang dapat digunakan dalam kehidupan sehari-hari (Muhson, 2010). Namun ketidakpuasan terhadap pembelajaran konvensional mendorong siswa untuk mencari alternatif pembelajaran lain yang mudah dipahami dan mudah diakses. Selain pembelajaran dengan les privat maupun bimbingan belajar, saat ini sedang berkembang pembelajaran online yang diminati para pelajar Indonesia. Perkembangan ini muncul seiring dengan perkembangan teknologi informasi berbasis web (internet). Pembelajaran online berbasis internet seperti Zenius, Quipper, dan Ruang Guru, saat ini menjadi alternatif pilihan model pembelajaran melalui internet. Begitu pula platform Edmodo dan Google Classroom semakin banyak digunakan dalam proses pembelajaran di sekolah.

Teknologi informasi di bidang pendidikan muncul sebagai bidang kajian yang terlibat dalam penyediaan fasilitas belajar. Pembelajaran dengan menggunakan teknologi informasi menuntut kreativitas dan kemandirian diri sehingga memungkinkan mengembangkan semua potensi yang dimiliki peserta didik. Melalui penggunaan teknologi informasi, setiap siswa akan termotivasi untuk belajar maju berkelanjutan sesuai dengan potensi dan kemampuan yang dimilikinya. Oleh karena itu penulis tertarik untuk mengidentifikasi inovasi pembelajaran melalui teknologi informasi, terutama berkaitan dengan pengembangan model pembelajaran melalui internet.

\section{METODE}

Penelitian ini menggunakan metode kualitatif dengan studi literatur (dokumen) atas hasil-hasil penelitian sebelumnya. Pengumpulan data dalam penelitian ini dilakukan dengan menelusuri buku-buku dan jurnal-jurnal pada 
beberapa media cetak maupun elektronik seperti buku, koleksi jurnal perpustakaan, dan internet. Penelusuran jurnal dilakukan melalui Google Cendekia. Kata kunci yang digunakan untuk penelusuran jurnal yaitu inovasi pembelajaran, teknologi informasi, model pembelajaran, dan pembelajaran melalui internet. Berdasarkan hasil penelusuran diperoleh dan dipilih data yang memenuhi kriteria, yaitu tentang pengembangan model pembelajaran melalui internet. Analisis data meliputi pengumpulan data, reduksi data, penyajian data, dan penarikan kesimpulan.

\section{HASIL DAN PEMBAHASAN \\ Inovasi Pembelajaran Melalui Teknologi Informasi}

Proses pembelajaran melibatkan keterhubungan antar komponen pembelajaran, baik komponen peserta didik, pendidik, media, materi pembelajaran, dan lingkungan pembelajaran (Abdulhak \& Darmawan, 2015). Upaya mengelola keterhubungan antara komponen pembelajaran ini agar menjadi lebih optimal, efektif, dan efisien dalam mencapai tujuan pembelajaran, berhubungan dengan pola atau model pembelajaran. Model pembelajaran ini akan berhubungan dengan desain, sistem, strategi, pemanfaatan media, pendekatan pembelajaran, serta teknologi informasi dan komunikasi.

Teknologi informasi merupakan studi atau penggunaan peralatan elektronika, terutama komputer, untuk menyimpan, menganalisis, dan mendistribusikan informasi apa saja, termasuk kata-kata, bilangan dan gambar (Kadir \& Triwahyuni, 2013). Perkembangan teknologi informasi yang mampu mengolah, mengemas, dan menampilkan, serta menyebarkan informasi pembelajaran baik secara audio, visual, audiovisual bahkan multimedia, saat ini telah mampu mewujudkan pembelajaran yang disebut dengan Virtual Learning. Konsep ini berkembang sehingga mampu mengemas setting dan realitas pembelajaran sebelumnya menjadi lebih menarik dan memberikan pengondisian secara psikologis adaptif kepada pembelajar dimanapun mereka berada (Darmawan, 2012). Perkembangan teknologi informasi memacu suatu baru dalam kehidupan yang dikenal dengan e-life (Al-jufri, 2015). Teknologi informasi telah mengintegrasikan program komputer berbasis internet sehingga muncul e-book, e-learning, e-journal, e-dictionary, e-lab, dan sebagainya. Internet memungkinkan orang dapat mengakses data dan bertukar informasi. Fasilitas internet dapat digunakan untuk melakukan banyak hal, antara lain dengan adanya fasilitas world-wide-web (Yakub \& Hisbanarto, 2014).

Pembelajaran berbasis web (internet) merupakan suatu kegiatan pembelajaran yang memanfaatkan media situs (website) yang bisa diakses melalui jaringan internet. Pembelajaran berbasis web (Web-Based Learning) merupakan salah satu bentuk e-learning yang materi (content) maupun cara penyampaiannya (delivery method) melalui internet (web). Pembelajaran berbasis web adalah sebuah pengalaman belajar dengan memanfaatkan jaringan internet untuk berkomunikasi dan menyampaikan informasi pembelajaran (Rusman, Kurniawan, \& Riyana, 2012).

Internet dapat menciptakan sebuah lingkungan belajar maya (Virtual Learning Environment). Penerapan virtual learning ditujukan untuk mengatasi masalah keterpisahan ruang dan waktu antara siswa dan pengajar melalui media komputer. Siswa dapat memperoleh bahan belajar yang sudah 
dirancang dalam paket-paket pembelajaran yang tersedia dalam situs internet. Dengan menerapkan virtual learning, siswa dapat mempelajari bahan belajar sendiri atau jika diperlukan siswa meminta bantuan dalam bentuk interaksi yang difasilitasi oleh komputer, seperti belajar berbantuan komputer (ComputerBased Learning/CBL) atau interactive web pages, belajar berbantuan pengajar atau tutor secara synchronous (dalam titik waktu yang sama) dan asynchronous (dalam titik waktu yang berbeda), atau belajar berbantuan sumber belajar lain seperti dengan siswa lain atau pakar, e-mail, dan sebagainya (Julaeha, 2011).

Salah satu nilai penting dari penggunaan web sebagai media pembelajaran, yaitu bahwa web dilengkapi dengan hyperlink yang memungkinkan untuk mengakses informasi secara acak (non linear) yang berdampak pada kecepatan untuk memperoleh informasi yang ada di dalam web. Materi pembelajaran berbasis web utamanya berupa tulisan yang harus dibaca. Dalam pembelajaran berbasis web juga dapat disertakan materi berupa simulasi untuk meningkatkan kemampuan motorik pembelajar. Selain itu, pembelajaran berbasis web dapat diperkaya dengan melakukan hal yang sebenarnya (Rusman, Kurniawan, \& Riyana, 2012).

Apabila dirancang dengan baik dan tepat, maka pembelajaran berbasis web bisa menjadi pembelajaran yang menyenangkan, memiliki unsur interaktivitas yang tinggi, menyebabkan peserta didik mengingat lebih banyak materi pelajaran, serta mengurangi biaya-biaya operasional yang biasanya dikeluarkan oleh peserta didik untuk mengikuti pembelajaran. Dikarenakan sifatnya yang maya/virtual, pembelajaran berbasis web dianggap telah memberikan fleksibilitas terhadap kegiatan pengaksesan materi pembelajaran.

\section{Klasifikasi Model-Model Pembelajaran Internet}

Kegiatan belajar yang menggunakan komputer dikenal dengan istilah Computer Based Instruction (CBI). Adapun model pembelajaran dengan komputer antara lain: 1) model drills, merupakan strategi pembelajaran melalui penyediaan latihan-latihan soal yang bertujuan untuk menguji penampilan siswa melalui kecepatan menyelesaikan soal-soal latihan yang diberikan program; 2) model tutorial, merupakan program pembelajaran yang digunakan dalam proses pembelajaran dengan menggunakan perangkat lunak berupa program komputer yang berisi materi pelajaran; 3) model simulasi, merupakan salah satu strategi pembelajaran yang bertujuan memberikan pengalaman belajar yang lebih konkret melalui penciptaan tiruan-tiruan bentuk pengalaman yang mendekati suasana yang sebenarnya; 4) model games atau permainan, dikembangkan atas pembelajaran menyenangkan, dimana peserta didik akan dihadapkan pada beberapa petunjuk dan aturan permainan. Pembelajaran didesain seolah peserta didik mengikuti permainan yang disajikan melalui simulasi-simulasi tertentu yang dibutuhkan agar peserta didik mampu menerapkan semua pengalaman belajarnya dalam menyelesaikan masalah yang dimaksud (Abdulhak \& Darmawan, 2015)

Menurut Haughey dalam Sa'ud (2018) ada tiga bentuk sistem pembelajaran melalui internet yang bisa dipertimbangkan sebagai dasar pengembangan sistem pembelajaran dengan mendayagunakan internet, yaitu web course, web centric course, dan web enhanced course. 
Web Course adalah penggunaan internet untuk keperluan pendidikan yang seluruh bahan ajar, diskusi, konsultasi, penugasan, latihan, ujian dan kegiatan pembelajaran lainnya sepenuhnya disampaikan melalui internet. Model ini menggunakan sistem jarak jauh dengan siswa dan guru sepenuhnya terpisah dan tidak diperlukan adanya tatap muka (Sa'ud, 2018). Siswa dan guru sepenuhnya terpisah, namun hubungan atau komunikasi antara peserta didik dengan pengajar bisa dilakukan setiap saat. Komunikasi lebih banyak dilakukan secara ansynchronous daripada secara synchronous. Bentuk web course ini tidak memerlukan adanya kegiatan tatap muka baik untuk keperluan pembelajaran maupun evaluasi dan ujian, karena semua proses pembelajaran sepenuhnya menggunakan fasilitas internet seperti e-mail, chat rooms, bulletin board dan online conference (Rofiq, 2011)

Selain itu, sistem ini biasanya juga dilengkapi dengan berbagai sumber belajar digital, baik yang dikembangkan sendiri maupun dengan membuat hubungan (link) ke berbagai sumber belajar yang sudah tersedia di internet, seperti, e-book, e-library, dan lain-lain. Bentuk pembelajaran model ini biasanya digunakan untuk keperluan pendidikan jarak jauh (distance education/learning). Aplikasi bentuk ini antara lain virtual campus ataupun lembaga pelatihan yang menyelenggarakan pelatihan-pelatihan yang bisa diikuti secara jarak jauh dan setelah lulus ujian akan diberikan sertifikat, seperti yang disediakan oleh situs www.indonesiax.co.id.

Web Centric Course adalah penggunaan internet yang memadukan antara belajar jarak jauh dan tatap muka (konvensional). Sebagian materi disampaikan melalui internet dan sebagian lagi melalui tatap muka (Sa'ud, 2018). Sebagian bahan ajar, diskusi, konsultasi, penugasan, dan latihan disampaikan melalui internet, sedangkan ujian serta sebagian konsultasi, diskusi, dan latihan dilakukan secara tatap muka. Meskipun dalam proses belajarnya sebagian dilakukan dengan tatap muka yang biasanya berupa tutorial, tetapi prosentase tatap muka tetap lebih kecil dibandingkan dengan prosentase proses pembelajaran melalui internet (Rofiq, 2011).

Bentuk ini memberikan makna bahwa kegiatan belajar bergeser dari kegiatan di kelas menjadi kegiatan melalui internet. Hampir sama dengan bentuk web course, siswa dan guru sepenuhnya terpisah. Akan tetapi, pada waktu-waktu yang telah ditetapkan, mereka bertatap muka, baik di sekolah maupun di tempat-tempat yang telah ditentukan seperti di ruang perpustakaan, taman bacaan, ataupun di balai pertemuan. Penerapan bentuk ini telah dilakukan pada perguruan tinggi-pergi terkemuka yang menggunakan sistem belajar secara off campus.

Web Enhanced Course adalah pemanfaatan internet untuk menunjang peningkatan kualitas pembelajaran yang dilakukan di kelas (Sa'ud, 2018). Kegiatan pembelajaran utamanya adalah tatap muka di kelas. Peranan internet disini adalah untuk menyediakan sumber-sumber belajar yang kaya akan informasi, dengan cara memberikan alamat-alamat atau membuat link ke berbagai sumber belajar yang sesuai dan bisa diakses secara online. Hal ini dilakukan untuk meningkatkan kuantitas dan memperluas kesempatan berkomunikasi antara pengajar dengan peserta didik secara timbal balik. Dialog atau komunikasi dua arah tersebut dimaksudkan untuk keperluan berdiskusi, berkonsultasi, maupun untuk bekerja secara kelompok (Rofiq, 2011). 
Berbeda dengan kedua bentuk sebelumnya, pada bentuk web enhanced course ini prosentase pembelajaran melalui internet justru lebih sedikit dibandingkan dengan prosentase pembelajaran secara tatap muka, karena penggunaan internet hanya untuk mendukung kegiatan pembelajaran secara tatap muka.

Baik pada model web course, web centric course, ataupun web enhanced course, terdapat beberapa komponen aktivitas seperti informasi, bahan ajar, pembelajaran maupun komunikasi, serta penilaian yang bervariasi. Secara umum, komponen aktivitas dan strukturnya dapat diterapkan dalam pengembangan pembelajaran melalui internet.

\section{Pengembangan Model Pembelajaran melalui Internet}

Sistem pembelajaran internet dapat dikembangkan melalui tiga cara pengembangan, yaitu: 1) menggunakan sepenuhnya fasilitas internet yang telah ada, seperti email, IRC (Internet Relay Chat), world wide web, search engine, milis (miling list) dan FTP (File Transfer Protocol); 2) menggunakan software pengembang program pembelajaran dengan internet yang dikenal dengan Web-Course Tools, yang di antaranya bisa didapatkan secara gratis ataupun bisa juga dengan membelinya. Ada beberapa vendor yang mengembangkan Web Course Tools seperti WebCT, Web Fuse, Top Class, dan lain-lain; 3) mengembangkan sendiri program pembelajaran sesuai dengan kebutuhan (tailor-made), dengan menggunakan bahasa pemrograman seperti ASP (Active Server Pages) dan lain-lain (Rofiq, 2011).

Setiap cara memiliki kelebihan dan kekurangan, misalnya pengembangan program pembelajaran dengan menggunakan fasilitas internet mempunyai kelebihan biayanya sangat murah dibandingkan yang lain. Namun, ada kekurangannya yaitu dalam pengelolaan agak sulit karena sifatnya tidak terintegrasi. Sedangkan jika menggunakan Web Course Tools atau pengembangan secara tailor-made biayanya jauh lebih mahal. Namun kelebihannya yaitu mudah dalam pengembangan dan pengelolaannya, lebih power full, dan sesuai dengan kebutuhan. Untuk memilih salah satu cara yang akan dipakai, ditentukan pada pertimbangan berdasarkan kajian terhadap berbagai hal tersebut.

\section{Implementasi Pengembangan Model Pembelajaran melalui Internet}

Teori belajar kognitif yang berakar pada teori pemrosesan informasi merupakan landasan dari pengembangan pembelajaran dengan teknologi. Teori ini memberikan kerangka umum bagi desainer pembelajaran dalam mengontrol kondisi belajar pada suatu lingkungan atau material pembelajaran. Istilah pembelajaran mengacu pada segala daya dan upaya yang sengaja dikondisikan untuk terjadinya proses belajar pada diri siswa. Sedangkan istilah belajar memiliki pengertian sebagai suatu proses fisik dan psikis pada diri siswa. Dimana seseorang yang mengalami peristiwa belajar akan berbeda keadaannya dengan kondisi sebelum dia mengalami belajar (Lestari, 2014).

Hal ini senada dengan pendapat Miarso (2007), bahwa pembelajaran adalah suatu usaha yang disengaja, bertujuan, dan terkendali agar orang lain belajar atau terjadi perubahan yang relatif menetap pada diri orang lain. Usaha ini dapat dilakukan oleh seseorang atau suatu tim yang memiliki kemampuan 
dan kompetensi dalam merancang dan atau mengembangkan sumber belajar yang diperlukan.

Perkembangan selanjutnya dipengaruhi oleh teori belajar konstruktivisme. Komputer dimanfaatkan untuk membantu siswa menemukan dan merumuskan pengetahuannya melalui interaksi dan eksplorasi sumbersumber belajar berbasis teknologi informasi. Selain itu, pemanfaatan teknologi dalam pembelajaran juga mendukung teori socio-constructivism, yakni siswa memperoleh pengalaman belajar secara bersama-sama dengan siswa lain atau melalui interaksi dengan para pakar dengan media komunikasi berbasis teknologi. Perkembangan terkini adalah pemanfaatan teknologi secara terpadu di dalam pembelajaran yang memadukan berbagai keterampilan dan fungsi teknologi dalam proses belajar mengajar. Adapun pembelajaran melalui internet yang memanfaatkan teknologi informasi ini antara lain bimbingan belajar online seperti Quipper, Ruangguru, dan Zenius serta platform Edmodo dan Google Classroom.

Pembelajaran biasanya berlangsung dengan metode face to face atau sistem langsung. Namun dengan berkembangnya teknologi sekarang ini, belajar tidak selalu harus berhadapan langsung antara guru dan murid. Belajar online bisa dibilang lebih efisien secara waktu dan tempat, karena dapat dilakukan di waktu senggang dan di manapun, selama koneksi internet lancar. Di Indonesia, banyak sekali website yang menyediakan atau menawarkan jasa belajar online. Ada beberapa di antaranya yakni Ruangguru, Quipper, dan Zenius. Semua website tersebut memiliki keunggulan pada sektor produk dan keefisienan cara belajarnya. Ruangguru, Quipper, dan Zenius memiliki metode belajar, cara belajar, dan sistem belajar yang berbeda.

Ruangguru telah memiliki lebih dari 6 juta pengguna serta telah mengelola lebih dari 150.000 guru yang menawarkan jasa di lebih dari 100 bidang pelajaran. Perusahaan start-up ini memiliki komitmen untuk menjadi mitra bagi pemerintah daerah demi memberikan pendidikan yang berkualitas melalui Learning Management System (LMS). Saat ini, Ruangguru sudah bekerja sama dengan 32 provinsi dan lebih dari 326 pemerintah kota dan kabupaten di Indonesia. Adapun produk-produk yang ditawarkan Ruangguru adalah ruang belajar, ruang lesonline, digital bootcamp, ruang uji, ruang les dan ruang kelas. Ruangguru juga menawarkan video belajar berlangganan, marketplace les privat, layanan bimbingan belajar on-demand, tryout ujian online, dan lain-lain. Berikut ini merupakan contoh tampilan ruang belajar yang terdapat dalam website Ruangguru 


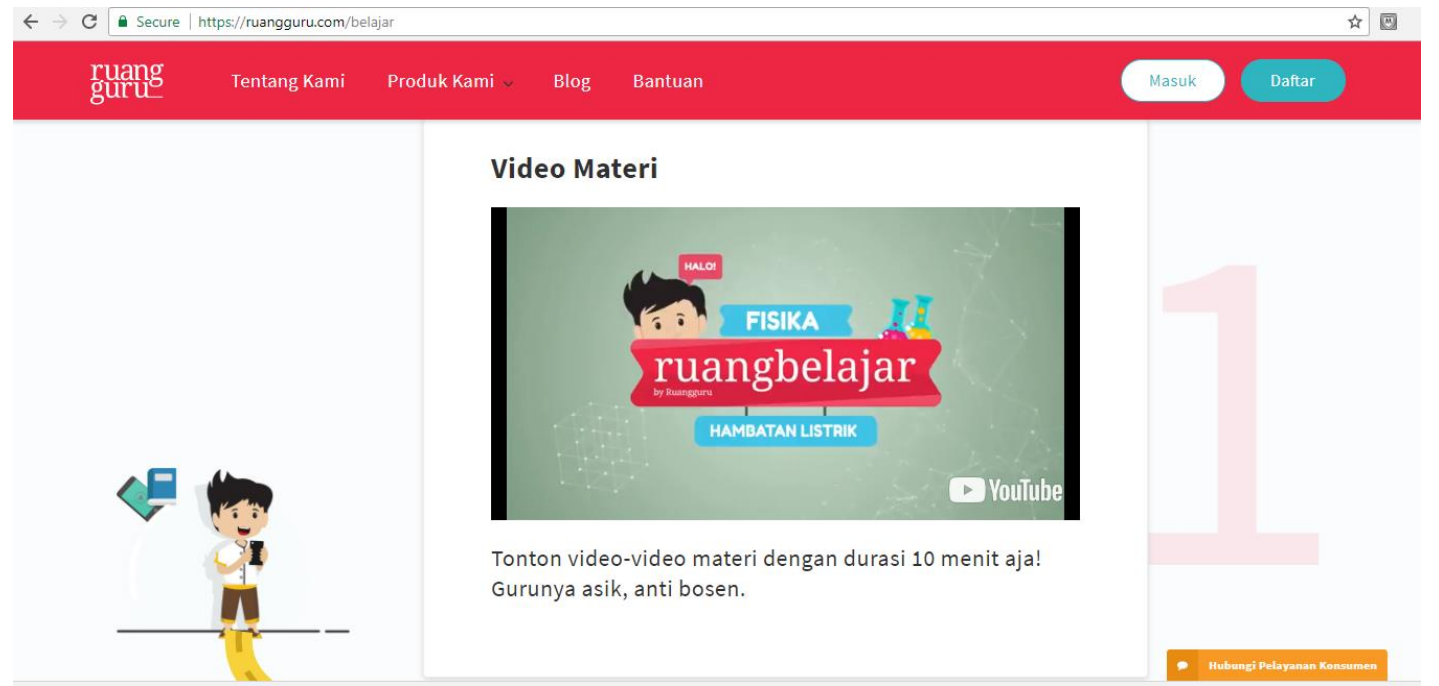

Sumber: https://ruangguru.com/belajar

Gambar 1. Tampilan Menu Ruang Belajar dalam Ruangguru

Quipper merupakan layanan untuk pendidikan tingkat menengah dan atas (SMP dan SMA) bagi siswa. Layanan ini tersedia di Indonesia dan beberapa negara lain, salah satunya adalah Filipina. Quipper telah bekerja sama dengan banyak sekolah-sekolah melalui produknya Quipper School. Guru dapat memberikan kelas online, serta memberikan tugas rumah kepada muridnya. Berikut ini merupakan contoh tampilan dari website Quipper.

\section{Quipper \\ Belajar Sepuasnya, Sekali Bayarnya!} Quipper Video adalah solusi belajar online untuk siswa SMP dan
SMA khususnya dalam persiapan menghadapi UN dan SEMPTN.
Dengan materi sesuai kurikulum nasional dan didukung oleh
tutor berkualitas, kamu bisa belujar sepuasnya hanya dengan
sekali bayar. Selesaikan pendaftaran untuk coba belajar gratis
sekarangt

\section{Mutai Belajart:}

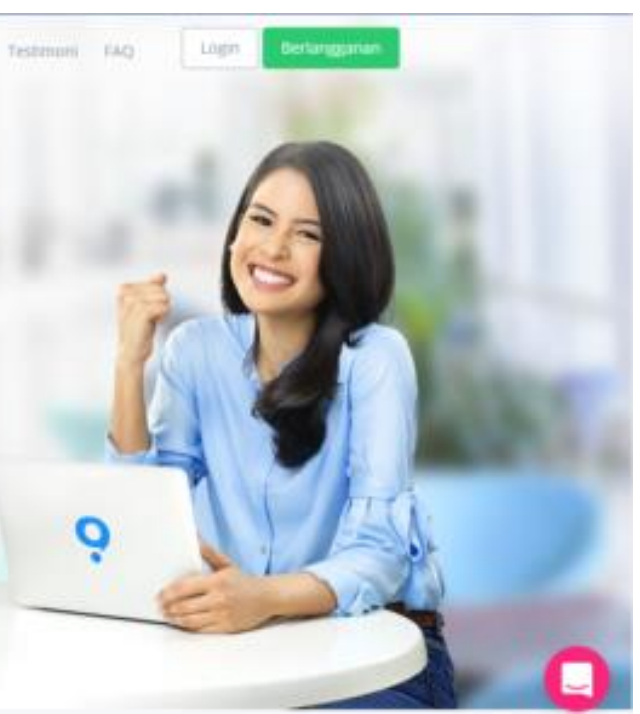

Sumber: https://www.quipper.com/id/video/ Gambar 2. Tampilan Menu Quipper

Quipper menyediakan layanan yang terdiri dari penyediaan secara online video pelajaran yang dikenal sebagai "Video Quipper" dan konten-konten lain seperti informasi, data, teks, musik, suara, foto, grafik atau materi-materi lain yang disediakan untuk tujuan belajar "Konten Non-Video Quipper". Video Quipper dan Konten Non-Video Quipper disebut juga sebagai "Konten Digital". Layanan tersebut dapat mengakses dan melihat konten digital dalam dua cara, 
yaitu dengan aliran video (streaming) untuk konten digital dalam bentuk video Quipper, dan dengan mengunduh suatu salinan untuk konten digital dalam bentuk konten non-video Quipper.

Selain Ruangguru dan Quipper, ada satu website belajar online yang bernama Zenius. Perusahaan yang bergerak pada bidang pendidikan di Indonesia ini telah memulai aktivitas bisnisnya sejak tahun 2004 dan terdaftar sebagai perusahaan resmi dalam bentuk Perseroan Terbatas (PT) pada tahun 2007. Zenius bisa digunakan sebagai media belajar online maupun offline, karena video materi belajar Zenius ada yang dalam bentuk VCD. Berikut ini merupakan contoh tampilan dari website Zenius

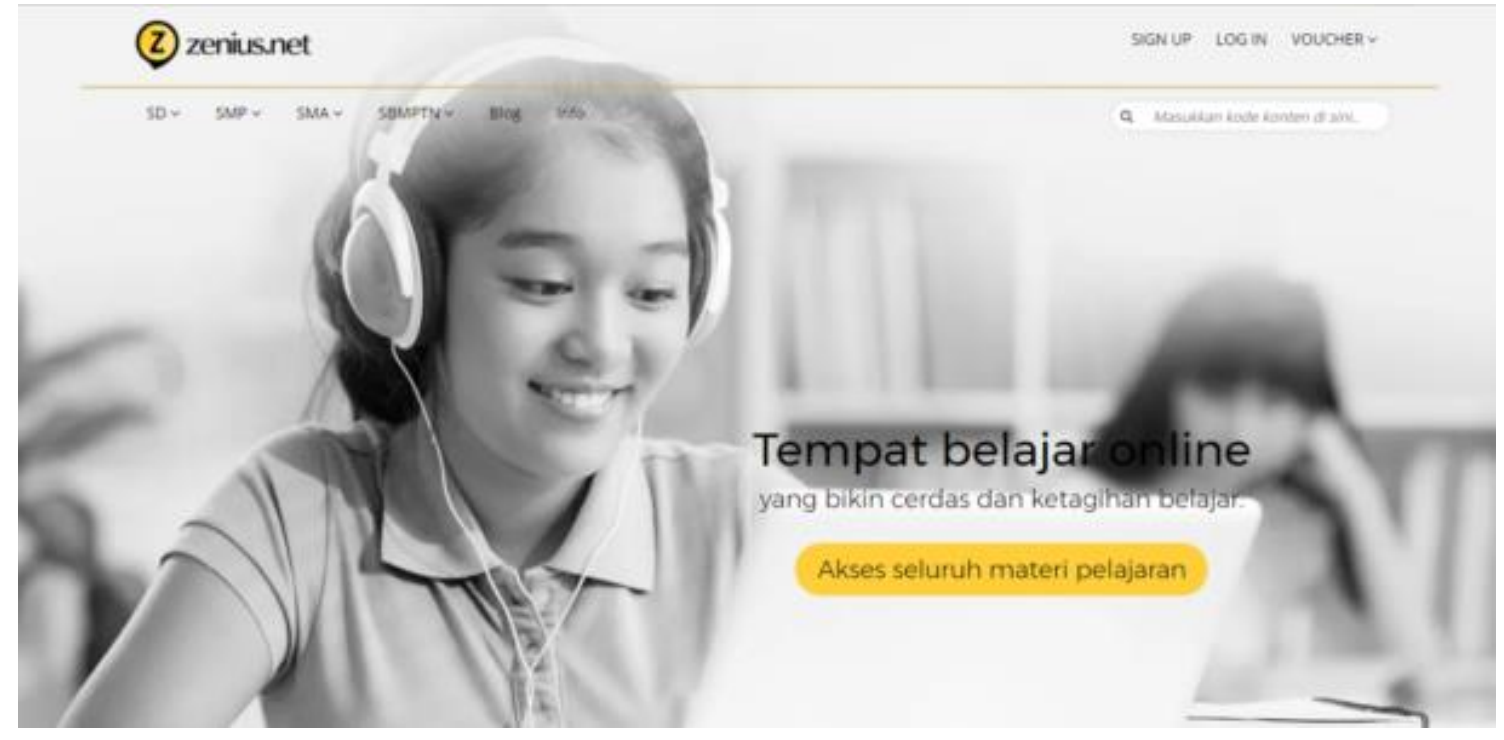

Sumber: https://www.zenius.net/

Gambar 3. Tampilan Menu Zenius

Secara garis besar, produk Zenius dibagi menjadi 3, yaitu: 1) website zenius.net, website ini berisi 66.000 video pembelajaran, 3.000 paket latihan soal, mencakup seluruh materi dari 15 mata pelajaran SD, SMP, SMA, pembahasan soal Ujian Nasional (tingkat SD-SMA), SBMPTN, dan berbagai Ujian Saringan Mandiri masuk PTN; 2) Paket Zenius Xpedia 2.0, merupakan paket lengkap untuk belajar baik secara online maupun offline. Di dalam paket Xpedia 2.0, terdapat akses belajar di zenius.net sampai akhir tahun ajaran, set DVD untuk jenjang kelas tertentu, dan forum belajar sesama pengguna Xpedia 2.0 di Zenius Club; 3) CD Multimedia, ada versi CD yang bisa ditonton di CD Player melalui PC maupun laptop yang berbasis Windows Operating System untuk yang memiliki kesulitan koneksi internet atau lebih memilih belajar secara offline; 4) Zenius Prestasi, merupakan produk yang dirancang khusus untuk guru dan sekolah yang dapat dipasang pada jaringan lokal sekolah. Zenius Prestasi berisi aplikasi yang memudahkan guru untuk merancang proses ujian. Mulai dari proses pembuatan soal, pelaksanaan ujian CBT, proses koreksi, dan proses evaluasi, semua bisa diotomasi secara digital. Selain itu, Zenius 
Prestasi juga menyediakan ribuan video pembahasan materi pelajaran sekolah yang telah disesuaikan dengan 3 varian kurikulum Indonesia.

Jenis media pembelajaran berbasis internet yang lain adalah Google Classroom. Google Classroom merupakan layanan online gratis untuk institusi pendidikan, lembaga non-profit, dan siapapun yang memiliki Akun Google. Google Classroom memudahkan peserta pembelajaran dan pengajar agar tetap terhubung, baik di dalam maupun di luar kelas. Google Classroom adalah platform pembelajaran campuran yang dikembangkan oleh Google untuk institusi pendidikan yang bertujuan menyederhanakan pembuatan, pendistribusian, dan penetapan tugas dengan cara tanpa kertas.

Layanan ini diperkenalkan sebagai fitur $G$ Suite for Education pada tanggal 6 Mei 2014, diikuti oleh rilis publiknya pada tanggal 12 Agustus 2014. Pada bulan Juni 2015, Google mengumumkan API Kelas dan tombol berbagi untuk situs web, yang memungkinkan administrator institusi pendidikan dan pengembang untuk selanjutnya terlibat dengan Google Classroom. Pada bulan Maret 2017, Google membuka kelas untuk mengizinkan pengguna Google pribadi masuk kelas tanpa persyaratan memiliki akun $G$ Suite for Education, dan pada bulan April, dimungkinkan bagi pengguna Google pribadi untuk membuat dan mengajar kelas. Google Classroom menggabungkan Google Drive untuk pembuatan tugas dan distribusi file atau dokumen, Google Dokumen, Spreadsheet, dan slide untuk menulis, Gmail untuk komunikasi, dan Google kalender untuk penjadwalan, dan penelusuran Google untuk membantu proyek institusi pendidikan.

Peserta pembelajaran dapat diajak ke kelas melalui database institusi, melalui kode pribadi, atau secara otomatis diimpor dari domain institusi pendidikan. Setiap kelas membuat folder terpisah di drive pengguna masingmasing, di mana peserta pembelajaran dapat mengirimkan karya untuk dinilai oleh seorang pengajar. Aplikasi seluler ,tersedia untuk perangkat berbasis iOS dan Android, pengguna bisa memanfaatkan melakukan berbagai aktifitas seperti mengambil foto dan melampirkan tugas, berbagi file dari aplikasi lain, dan mengakses informasi secara offline. Pengajar dapat memantau kemajuan setiap peserta pembelajaran, dan setelah dinilai, pengajar dapat kembali bekerja, dengan komentar, agar peserta pembelajaran merevisi dan memperbaiki tugas. Pengajar dapat memposting pengumuman ke ruang kelas yang telah dibuat, dan peserta pembelajaran bisa berinteraksi dengan menuliskan komentar.

Model pembelajaran berikutnya adalah You-Do merupakan model pembelajaran inovatif yang memungkinkan siswa untuk menguasai materimateri pembelajaran secara mudah, karena dirancang dengan bantuan multimedia digital online YouTube dan Edmodo yang digunakan untuk meningkatkan kemampuan digital literacy siswa.

YouTube merupakan sebuah situs web berbagi video yang memungkinkan pengguna mengunggah, menonton, dan berbagi video. Situs YouTube ini berisi konten-konten atau informasi yang sangat bervariasi seperti konten pendidikan, sosial, ekonomi, budaya, hiburan, dan lain-lain, yang disajikan dalam bentuk video multimedia secara online yang bisa ditonton kapanpun dan dimanapun di seluruh pelosok dunia. 
Edmodo merupakan platform pembelajaran berbasis jejaring sosial yang diperuntukkan untuk guru, murid, sekaligus orangtua murid. Edmodo merupakan program e-learning yang menerapkan sistem pembelajaran yang mudah dan efisien sekaligus lebih menyenangkan. Edmodo memiliki desain yang mirip dengan facebook, sehingga sangat mudah untuk digunakan.

Edmodo dikembangkan berdasarkan prinsip-prinsip pengelolaan kelas berbasis grup dan media sosial. Fitur penting dari edmodo ialah dukungan aktif terhadap model komunikasi dari fasilitas sosial online atau daring (dalam jaringan) yang ditambah dengan fitur bahan ajar daring dan evaluasi daring.

Adapun fitur-fitur yang terdapat pada Edmodo adalah sebagai berikut: 1) Polling, merupakan salah satu fitur yang hanya dapat digunakan oleh guru. Fitur ini biasanya digunakan oleh guru untuk mengetahui tanggapan siswa mengenai hal tertentu; 2) Gradebook, fitur ini mirip seperti catatan nilai siswa. Dengan fitur ini, guru dapat memberi nilai kepada siswa secara manual maupun otomatis. Fitur ini juga memungkinkan seorang guru untuk mengatur penilaian hasil belajar siswa; 3) Quiz, fitur ini hanya dapat dibuat oleh guru, sedangkan siswa tidak mempunyai akses untuk membuat quiz. Mereka hanya bisa mengerjakan soal quiz yang diberikan oleh guru. Quiz digunakan oleh guru untuk memberikan evaluasi online kepada siswa berupa pilihan ganda, benar salah, jawaban pendek, soal uraian, maupun mencocokkan; 4) File and Links, fitur ini berfungsi untuk mengirimkan note dengan lampiran file dan link. Biasanya file tersebut berekstensi .doc, .ppt, .xls, .pdf, dan lain-lain; 5) Library, dengan fitur ini, guru dapat mengunggah bahan ajar seperti materi, presentasi, gambar, video, sumber referensi, dan lain-lain. Fitur ini juga berfungsi sebagai wadah untuk menampung berbagai file dan link yang dimiliki oleh guru maupun murid; 6) Assignment, fitur ini digunakan oleh guru untuk memberikan tugas kepada murid secara online. Kelebihan fitur ini yaitu dilengkapi dengan waktu deadline, attach file yang memungkinkan siswa untuk mengirimkan tugas secara langsung kepada guru dalam bentuk file dokumen ( $p d f$, doc, xls, ppt) dan juga tombol "Turn in" pada kiriman assignment yang berfungsi menandai bahwa siswa telah menyelesaikan tugas mereka; 7) Award Badge, untuk memberikan suatu penghargaan kepada siswa atau grup, biasanya guru menggunakan fitur ini; 8) Parent Code, dengan fitur ini, orang tua murid dapat memantau aktifitas belajar yang dilakukan anak-anak mereka.

Cecep Gaos merancang rencana pelaksanaan pembelajaran digital literacy ini dengan nama model pembelajaran You-Do. Model pembelajaran ini berbasis media online atau daring (dalam jaringan). You-Do adalah singkatan dari YouTube dan Edmodo.

Rancang model pembelajaran You-Do ini menggunakan dua media digital online, yaitu YouTube dan Edmodo. YouTube bisa diakses melalui alamat www.youtube.com, sedangkan Edmodo bisa diakses melalui alamat www.edmodo.com. Model pembelajaran You-Do ini bisa diaplikasikan pada semua mata pelajaran dan semua jenjang pendidikan. Secara sederhana, model pembelajaran You-Do ini digambarkan dalam sebuah alur berikut ini. 


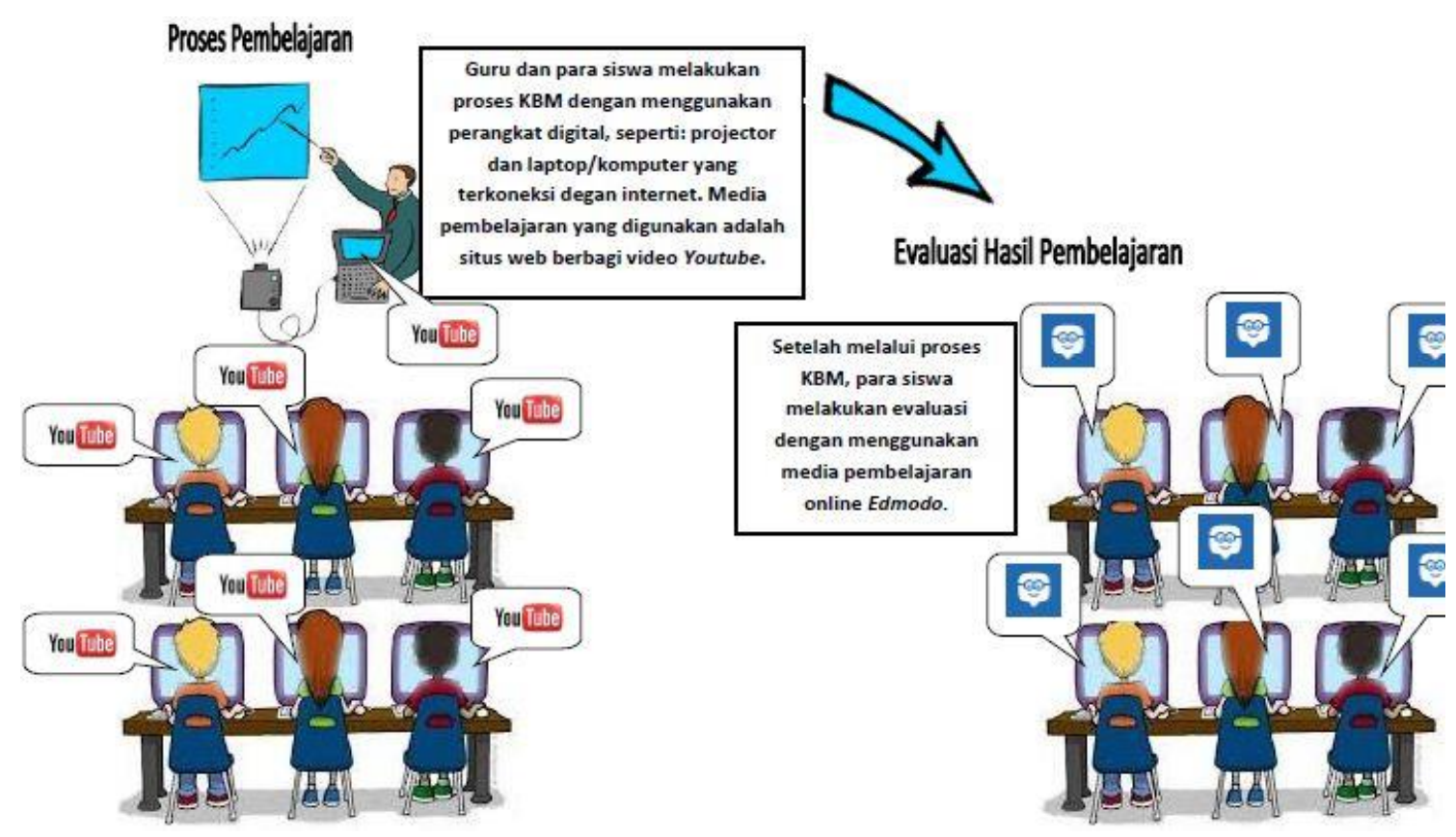

Sumber: https://www.literahati.com/2019/01/

Gambar 4. Alur Proses Pembelajaran You-Do

Kegiatan pembelajaran model You-Do ini berlangsung di dalam laboratorium komputer yang terkoneksi dengan internet. Di awal pembelajaran, anak-anak diberi penjelasan tentang tujuan pembelajaran yang hendak dicapai. Kemudian masuk kepada proses pembelajaran. Kegiatan pembelajaran mengadaptasi pendekatan ilmiah dengan kegiatan 5M, yaitu Mengamati (Observing), Menanya (Questioning), Mengumpulkan informasi (Experimenting), Menalar/Mengasosiasi (Associating), dan Mengomunikasikan (Communicating). Pada proses mengamati, anak-anak diberikan link YouTube untuk melihat sebuah cuplikan video tentang materi pembelajaran. Setelah anak-anak dapat membuka link YouTube tersebut, lalu mereka menonton dan mempelajari materi yang disajikan di dalam video tersebut.

Lalu, anak-anak masuk pada kegiatan bertanya tentang materi-materi yang dipelajari. Setelah itu, anak-anak diberi kesempatan untuk melakukan kegiatan mengumpulkan informasi lain yang terkait dengan materi pembelajaran pada kolom pencarian yang ada di YouTube. Setelah itu, mereka melakukan kegiatan menalar dan mengomunikasikan hasil pembelajaran yang telah mereka lakukan.

Pada kegiatan evaluasi atau penilaian, penulis menggunakan Edmodo untuk menilai sejauh mana pemahaman mereka terhadap materi yang telah dipelajari secara online. Untuk melaksanakan kegiatan penilaian melalui Edmodo ini, setiap siswa harus sudah memiliki akun Edmodo sebagai siswa. Lalu mereka bergabung di grup yang sudah dibuat dengan cara memasukkan kode grupnya.

Setelah bisa bergabung di grup, mereka bisa mengerjakan evaluasi/penilaian dengan mengerjakan quiz yang sudah penulis buat di grup Edmodo tersebut. Setelah mereka mengerjakan soal-soal evaluasinya, hasilnya secara otomatis terbukukan di akun Edmodo guru dan bisa diekspor dalam bentuk file $x / s$. 
Siswa menganalisis dan mensintesiskan informasi yang mereka miliki agar pembelajaran yang dalam dapat terjadi. Kerap kali tindakan informasi analisis berhasil mensintesiskannya, mengambil bagian dari informasi dan selanjutnya mereorganisasinya menjadi apa saja atau sesuatu yang berbeda. Namun ada saatnya ketika siswa hanya ingin menganalisis informasi atau hanya mensintesiskan informasi (Jensen \& Nickelsen, 2011).

Dalam model pembelajaran You Do ini, informasi dari YouTube dianalisis kemudian disintesis. Hasil siswa berselancar atau searching di internet/Google/YouTube ini digabungkan antara analisis dan sintesis sehingga menghasilkan kreativitas, bisa berupa pemikiran baru (abstrak) atau temuan barang teknologi baru yang mampu menjawab (solusi) masalah yang terjadi dalam kehidupan manusia.

\section{SIMPULAN}

Berbagai upaya telah dilakukan oleh dunia pendidikan untuk meningkatkan kualitas pendidikan, khususnya kualitas pembelajaran melalui pemanfaatan teknologi berbasis internet. Selain fungsinya sebagai alat bantu pemecahan masalah manusia, juga dapat dimanfaatkan untuk mendukung proses pembelajaran. Model pembelajaran melalui internet yang perlu dipertimbangkan sebagai dasar pertimbangan sistem pembelajaran dengan menggunakan internet adalah web course, web centric course dan web enhanced course. Masing-masing memiliki keunggulan dan kelemahan bergantung dari sudut mana kebutuhan itu dapat dipenuhi.

Berdasarkan kajian dan pertimbangan selanjutnya pengembangan sistem pembelajaran dapat dilakukan melalui sepenuhnya fasilitas internet yang telah ada, software pengembang program pembelajaran dengan internet web course tools, dan pengembangan sendiri program pembelajaran. Masingmasing cara dapat dipilih bergantung model yang akan dipakai dalam implementasi pembelajaran melalui internet. Namun pada dasarnya, mendayagunakan internet untuk mendukung peningkatan kualitas pendidikan perlu segera dilaksanakan secara luas di institusi-institusi penyelenggara pendidikan di Indonesia.

\section{REFERENSI}

Abdulhak, I., \& Darmawan, D. (2015). Teknologi Pendidikan . Bandung: Remaja Rosdakarya.

Al-jufri, H. (2015). Sistem Informasi Manajemen Pendidikan. Jakarta: Smart Grafika.

Darmawan, D. (2012). Inovasi Pendidikan: Pendekatan Praktik Teknologi Multimedia dan Pembelajaran Online. Bandung: Remaja Rosdakarya.

Jensen, E., \& Nickelsen, L. (2011). Deeper Learning: 7 Strategy Luar Biasa untuk Pembelajaran yang Mendalam dan Tak Terlupakan. Jakarta: Indeks.

Julaeha, S. (2011). Virtual Learning:: Pemanfaatan Teknologi Informasi dan Komunikasi untuk Meningkatkan Kualitas Pembelajaran. Majalah IImiah 
No.

2

Tahun

2011

$1-9$.

https://journal.uny.ac.id/index.php/mip/article/view/6868

Kadir, A., \& Triwahyuni, T. C. (2013). Pengantar Teknologi Informasi. Yogyakarta: Andi Offset.

Lestari, A. S. (2014). Pemanfaatan Teknologi Informasi dalam Pendidikan Karakter. Jurnal Shautut Tarbiyah Vol. 20 No. 2, 1-20. http://dx.doi.org/10.31332/str.v20i2.21

Miarso, Y. (2007). Menyemai Benih Teknologi Pendidikan. Jakarta: Kencana.

Muhson, A. (2010). Pengembangan Media Pembelajaran Berbasis Teknologi Informasi. Jurnal Pendidikan Akuntansi Indonesia Vol. VIII No. 2, 1-10. https://doi.org/10.21831/jpai.v8i2.949

Prasetyo, D. (2017). Pengembangan Model Pembelajaran Berbasis TIK: ELearning Materi Enterpreneurship di Kampus Komunitas Mandiri Bogor. Ganec Swara Vol. 11 No. 1, 51-56. http://unmasmataram.ac.id/2017/03/18/8-dwi-prasetyo/

Rofiq, M. N. (2011). Menggagas Model Pembelajaran Melalui Internet. Jurnal Falasifa Vol. 2 No. 2, 97-106.

Rusman, Kurniawan, D., \& Riyana, C. (2012). Pembelajaran Berbasis Teknologi Informasi dan Komunikasi: Mengembangkan Profesionalitas Guru. Jakarta : Rajawali Pers.

Sa'ud, U. S. (2018). Inovasi Pendidikan. Bandung: Alfabeta.

Yakub, \& Hisbanarto, V. (2014). Sistem informasi Manajemen Pendidikan. Yogyakarta: Graha IImu 